Tomasz Pawlonka

Joanna Bereżnicka

Szkoła Glówna Gospodarstwa Wiejskiego w Warszawie

\title{
Zarządzanie oparte na wartości - filozofia i wyzwanie w zarządzaniu finansami współczesnego przedsiębiorstwa
}

\section{VALUE-BASED MANAGEMENT - PHILOSOPHY \\ OR THE CHALLENGE OF MANAGING THE FINANCES OF TODAY'S BUSINESS}

Prowadzenie działalności gospodarczej wymaga uprzedniego zdefiniowania celu działania przedsiębiorstwa oraz określenia środków którymi ten cel (te cele) będq osiagane. Odzwierciedleniem filozofii działania przedsiębiorstwa sq zatem misja $i$ wizja zdefiniowane $w$ postaci celów strategicznych oraz celów operacyjnych umożliwiajacych realizacje dlugoterminowych planów i zamierzeń. Sama strategia z kolei jest wyrazem przyjętej koncepcji biznesu oraz określonych sposobów umożliwiajacych przedsiębiorstwu zachowanie korzystnej stabilności względem otoczenia . Celem artykulu jest prezentacja różnych koncepcji zarzadzania wartościq $w$ kontekście traktowania ich jako istoty funkcjonowania przedsiębiorstwa. Praca ma charakter przegladowy, a przy realizacji celu postużono się analiza opisowa.

Słowa kluczowe: Wartość przedsiębiorstwa, zarządzanie przez wartość dla właścicieli, zysk

\section{Wprowadzenie}

Prowadzenie działalności gospodarczej wymaga uprzedniego zdefiniowania celu działania przedsiębiorstwa oraz określenia środków którymi ten cel (cele) będą osiągane. Zatem misja i wizja zdefiniowane w postaci celów strategicznych oraz celów operacyjnych umożliwiających realizację długoterminowych planów i zamierzeń ${ }^{1}$ są odzwierciedleniem filozofii działalności przedsiębiorstwa. Sama strategia z kolei jest wyrazem przyjętej koncepcji biznesu oraz określonych sposobów umożliwiających przedsiębiorstwu zachowanie korzystnej stabilności względem otoczenia ${ }^{2}$. W rezultacie zmiany zachodzące w globalnej gospodarce powodują występowanie trzech głównych sił wymuszających na przedsiębiorcach zmianę sposobu myślenia. Siły te to: przyrost i ekspansja prywatnego kapitału, globalizacja rynków oraz rewolucja informatyczna.

Celem artykułu jest dyskusja naukowa na temat filozofii zarządzania opartej na wartości, jako istoty funkcjonowania przedsiębiorstwa we współczesnym świecie oraz problemów jej towarzyszących. Praca ma charakter przeglądowy, a przy realizacji celu posłużono się analizą opisową.

\footnotetext{
E. Maćkowiak: Ekonomiczna wartość dodana. Mierniki oceny kondycji finansowej i wartości przedsiębiorstwa, PWE, Warszawa, 2009, s. 13.
}

M. Moszkowicz: Strategia przedsiębiorstwa okresu przemian, PWE, Warszawa, 2000, s. 34. 


\section{Od zysku do wartości - zmiana paradygmatu celów przedsiębiorstwa}

Dotychczasowe definiowanie celu przedsiębiorstwa na podstawie zysku księgowego bądź też miar opierających się w swej konstrukcji na zysku netto wydaje się być we współczesnym świecie absolutnie niewystarczające. Koncentracja na zyskowności i późniejsza polityka podziału zysku sprawiły, że środki były reinwestowane w niepewne przedsięwzięcia a celem była dywersyfikacja prowadzonej działalności. W rezultacie, ceny akcji wielu przedsiębiorstw znacząco spadły tworząc pewną lukę występującą między bieżącą ceną akcji a ceną akcji możliwą do osiągnięcia przy efektywniejszym wykorzystaniu posiadanego przez firmę majątku. Siłą sprawczą powstania luki wartości jest również asymetria informacji oraz zróżnicowane oczekiwania poszczególnych interesariuszy ${ }^{3}$. Powstanie luki wartości (value gap) stanowiło dla potencjalnych agresorów niezwykle cenny bodziec i zachętę do przejęcia przedsiębiorstwa. Aby ustrzec się przed tego typu działalnością należało wprowadzić taki mechanizm oceny, który umożliwiłby prowadzenie działalności gospodarczej w taki sposób, aby dążyło ono do maksymalizowania wartości rynkowej ${ }^{4}$.

W krajowej i zagranicznej literaturze przedmiotu powszechnie wskazuje się maksymalizację wartości przedsiębiorstwa jako główny cel jego działania ${ }^{5}$. Zwiększanie wartości przedsiębiorstwa wydaje się być we współczesnym rozumieniu biznesu najlepszym przejawem służenia właścicielom ${ }^{6}$. Jak podkreśla A. Cwynar ${ }^{7}$, zarządzanie przedsiębiorstwem ukierunkowane na zwiększanie jego wartości stanowi jednoznaczny i łatwo weryfikowalny cel, który ma charakter holistyczny. Dzięki temu możliwa jest syntetyzacja kluczowych rozwiązań z innych, również istotnych, teorii zarządzania i finansów. Jak zauważa Wallace ${ }^{8}$, zwiększanie wartości jest celem komplementarnym łączącym oczekiwania zarówno właścicieli jak i pozostałych podmiotów zainteresowanych rozwojem przedsiębiorstwa. Jego zdaniem koncepcja „zarządzania przez wartość dla właścicieli” może być wręcz utożsamiana z „koncepcją zarządzania wartością wyników oczekiwanych przez różnych interesariuszy" i prowadzi niechybnie do niezwykle pożądanego we współczesnej gospodarce zwiększania zasobów intelektualnych i pozamaterialnych $\mathrm{w}$ przedsiębiorstwach. Poszerzające się grono interesariuszy zainteresowanych rozwojem i zwiększaniem wartości przedsiębiorstwa sprawia, że uprawnione jest stwierdzenie, iż jest to koncepcja oddziaływująca pozytywnie na rozwój całej gospodarki ${ }^{9}$. Cel w postaci zwiększania wartości

T. Majewski: Audyt wartości przedsiębiorstwa, Magazyn CEO, listopad 2006, dostęp: www.ceo.cxo.pl/artykuly, 04.08.2014 r., 2006, s. 1-4.

4 A. C. Shapiro, S. D. Balbirer: Modern Corporate Finance. A Multidisciplinary Approach to Value Creation, Prentice-Hall, Upper Saddle River, New Jersey, 2000, s. 8.

E. Maćkowiak: Op. cit., 2009, s. 17, 37.

6 N. Fera: Using Shareholder Value to Evaluate Strategic Choices, Management Accounting, November, 1997, s. 5.

7 A. Cwynar: Analiza porównawcza wybranych mierników zysku rezydualnego, Konsorcjum Akademickie, Kraków - Rzeszów - Zamość, 2010, s. 21.

$8 \quad$ J. S. Wallace: Value-Based Management and Shareholder Theory: Substitutes or Complements?, Working Paper, University of California, Irvine, 2002, s. 7-9.

9 J. Bughin, T. E. Copeland: The virtuous cycle of shareholder value creation, The McKinsey Quarterly, nr 2/1997, New York, 1997, s. 157-167.

T. Koller, M. Goedhart, D. Wessels: Valuation. Measuring and Managing the Value of Companies, $4^{\text {th }}$ Editon, John Wiley and Sons, New York, 2005, s. 136. 
przedsiębiorstwa łączy $\mathrm{w}$ sobie zarówno narzędzia jak i metody zarządzania finansowego i strategicznego, co pozwala pracownikom (a w szczególności menadżerom) na precyzyjne zrozumienie ekonomicznych i pozaekonomicznych determinant efektywności przedsiębiorstwa - zarówno w aspekcie krótko- jak i długookresowym. Cel określany jako maksymalizacja wartości przedsiębiorstwa jest zgodny z celem zapewnienia długoterminowego funkcjonowania firmy. Stwarza on bowiem możliwości rozwoju przedsiębiorstwa i obejmuje zdolność utrzymania pozycji strategicznej, pozycji finansowej oraz związków z właścicielami kapitału ${ }^{10}$. Cel ten zgodny jest ponadto $\mathrm{z}$ logiką inwestycyjną, przy czym zwiększanie wartości przedsiębiorstwa możliwe jest jedynie wtedy, gdy osiągnięta stopa zwrotu $\mathrm{z}$ zainwestowanego kapitału przewyższy minimalną wymaganą stopę zwrotu, czyli koszt kapitału $^{11}$. Stwierdzenie to stanowi podstawę funkcjonowania przedsiębiorstw we współczesnej myśli i koncepcji finansów przedsiębiorstw ${ }^{12}$.

Zauważyć należy jednak, że współczesne koncepcje i teorie finansów przedsiębiorstw nie są w pełni wolne i niezależne od ograniczeń, trudności i kosztów zdiagnozowanych $w$ ramach ewolucji teorii ekonomii. To powoduje postulat odejścia od imperatywu „maksymalizacja wartości” na rzecz „zwiększania wartości”"13 , a czynnikiem sugerującym taką konieczność jest koncepcja Simona wskazująca na brak pełnej racjonalności. Homo oeconomicus działający racjonalnie, maksymalizujący użyteczność oraz wybierający zawsze najlepsze warianty działania winien zostać zastapiony człowiekiem poszukującym rozwiązań satysfakcjonujących, zadowalających ${ }^{14}$. Ocena wyborów przedsiębiorcy (menadżera) jest rezultatem doświadczenia wzmocnionego wyobraźnią oraz indywidualnymi preferencjami, co sprawia, że dokonane wybory jedynie aspirują do bycia optymalnymi, choć nie muszą nimi byćc ${ }^{15}$. Powodów ograniczonej racjonalności należy doszukiwać się w niedostatecznej informacji oraz w jej asymetrii. W efekcie struktura wyborów dokonywanych przez przedsiębiorców przypomina raczej mechanizm „bodziec - reakcja” niż model racjonalnego wyboru między poznanymi alternatywami. To przekłada się na podejmowanie decyzji w zakresie osiągania głównego celu działania przedsiębiorstw jakim jest dążenie do zwiększania wartości przedsiębiorstwa ${ }^{16}$. W rezultacie mając na uwadze „maksymalizację wartości przedsiębiorstwa” wskazać należy, że jest ona utożsamiana z zasadą „im więcej tym lepiej”, a w efekcie sam termin „maksymalizacja” winien zostać przedstawiony jako

10 E. Unzeitig,D. D. Köthner: Shareholder Value Analyse. Entscheidung zur unternehmerrischen Nachhaltigkeit, Schäffer-Poeschel Verlag, Stuttgart, 1995, s. 9.

11 T. A., Pawlonka: Pomiar kosztu kapitału na przykładzie przedsiębiorstw branży mięsnej w Polsce: metodyczne studium przypadku, Wydawnictwo SGGW, Warszawa, 2016, s. 21-35.

J. Franc-Dąbrowska, P. Kobus: Koszt kapitału własnego - dylematy wyceny, Zagadnienia Ekonomiki Rolnej 1 (330), 2012, s. 77-89.

12 A. Damodaran: Finanse korporacyjne. Teoria i praktyka, wyd. 2, Onepress, Gliwice, 2007, s. 39.

13 J. Nowicki: Zwiększanie wartości dla właścicieli a cel działania przedsiębiorstwa w teorii firmy, Zeszyty Naukowe Uniwersytetu Szczecińskiego, nr 737, Finanse, rynki finansowe, ubezpieczenia, nr 56, Szczecin, 2012, s. 203.

14 J. G. March, H. A. Simon: Teoria organizacji, PWN, Warszawa, 1964, s. 228. M. Augier, E. Feigenbaum: Herbert Simon - Biographical Memoirs, Proceedings of the American Philosophical Society, Vol. 147, No. 2, 2003, s. 196

15 H. A. Simon: Działanie administracji. Proces podejmowania decyzji w organizacjach administracyjnych, PWN, Warszawa, 1976, s. 181.

16 H. Leibenstein: Poza schematem "homo oeconomicus", PWN, Warszawa, 1988, s. 121-122. 
„Zwiększanie”. W konsekwencji główny cel przedsiębiorstwa w postaci zwiększania jego wartości określany jest niekiedy jako koncepcja poszukiwania wartości (value seeking ${ }^{17}$. ale jest to kierunek, $\mathrm{w}$ którym współcześnie funkcjonujące przedsiębiorstwa powinny podążać. Zdaniem Szablewskiego ${ }^{18}$, współczesne realia wymagają nie tylko zwrócenia szczególnej uwagi na znaczenie i wpływ akcjonariuszy na przedsiębiorstwo, ale również zapewnienia koegzystencji i zachowania trwałej równowagi między interesami zróżnicowanych podmiotów, tj. grupy, organizacji, organów administracji lokalnej i centralnej oraz innych interesariuszy. Próba równoważenia interesów różnych grup interesariuszy stała się przyczynkiem do nowego spojrzenia na istotę funkcjonowania przedsiębiorstwa i powstania koncepcji VBM (zarzadzanie oparte na wartości - Value-Based Management).

\section{VBM - koncepcja funkcjonowania współczesnego przedsiębiorstwa}

Przyjęcie zwiększania wartości przedsiębiorstwa jako nadrzędnego celu wymusiło zmiany w strategiach rozwoju firm podporządkowanych koncepcji VBM ${ }^{19}$. Stwierdzono, że zwiększanie wartości przedsiębiorstwa jest celem niezwykle konkretnym, precyzyjnym, zorientowanym na przyszłość i dodatkowo motywującym menadżerów do podejmowania trafniejszych decyzji inwestycyjnych (z uwzględnieniem relacji dochódryzyko ${ }^{20}$. Koncepcja VBM miała być odpowiedzią na pojawiające się $\mathrm{w}$ realnym biznesie problemy i trudności $i^{21}$. Przejawia ona charakter, który pomimo pozornego prymatu akcjonariuszy (właścicieli), pozwala na zwiększanie wartości także dla innych interesariuszy. Koncepcja ta określana jest niekiedy jako filozofia zarządzania, która wykorzystuje narzędzia analityczne i procesy do skupienia pojedynczych obiektów, podmiotów organizacji wokół tworzenia wartości dla właścicieli ${ }^{22}$. Jej bieżąca postać jest wynikiem ewolucji szeregu poglądów. W tabeli 1 przedstawiono $\mathrm{w}$ ujęciu chronologicznym teorie i koncepcje mające fundamentalny wpływ na bieżącą postać VBM.

Tabela 1. Etapy ewolucji koncepcji VBM

\begin{tabular}{|l|l|ll|}
\hline Kto? & Kiedy? & Co? & \\
\hline Marshall A. & 1890 r. & Teoria dochodu rezydualnego & \\
\hline Modigliani F., Miller M. & $\begin{array}{l}1958 \text { r., 1961 r., } \\
1963 \text { r. }\end{array}$ & $\begin{array}{l}\text { Teoria optymalnej struktury kapitału, polityki } \\
\text { dywidendy i wyceny akcji }\end{array}$ & \\
\hline
\end{tabular}

17 M. C. Jensen: Value Maximization. Stakeholder Theory and the Corporate Objective Function, Journal of Applied Corporate Finance, Vol. 14, No. 3, 2001, s. 11.

18 A. Szablewski: Źródła i pomiar wartości firmy, [w:] Wycena i zarządzanie wartością firmy, [red.]

Szablewski A., Tuzimek R, Poltext, Warszawa, 2004, s. 37.

A. Szablewski: Budowanie wartości i społecznej odpowiedzialności przedsiębiorstwa, [w:] Value Based Management - koncepcja, narzędzia, przykłady, [red.] Szablewski A., Pniewski K., Bartoszewicz B., Poltext, Warszawa, 2008, s. 28.

19 P. Haspeslagh, T. Nodo, F. Boulos: Zarządzanie wartości firmy to nie tylko sprawa liczb, Harvard Business Review Polska, nr 7/2003, 2003, s. 103.

20 E. Maćkowiak: Op. cit., 2009, s. 17.

21 A. Rappaport: Creating Shareholder Value. The New Standard for Business Performance, The Free Press, A Division of Macmillan, New York, 1986, s. 77.

22 J. Condor, J. Goldstein: Value Based Management - The Only Way to Manage for Value, Accountancy Ireland, Vol. 30, I. 5, 1998, s. 10. 


\begin{tabular}{|c|c|c|}
\hline Sharp W. & $1964 \mathrm{r}$. & Model wyceny aktywów kapitałowych (CAPM) \\
\hline Jensen M., Meckling W. & $1975 \mathrm{r}$. & Teoria agencji \\
\hline Rappaport A. & $1986 \mathrm{r}$. & Koncepcja kreowania wartości dla właścicieli (VBM) \\
\hline $\begin{array}{l}\text { Copeland T., Koller T., } \\
\text { Murrin J. i Damodaran A. }\end{array}$ & $\begin{array}{l}\text { Lata 90-te XX } \\
\text { wieku }\end{array}$ & $\begin{array}{l}\text { Metody wyceny, zarządzanie wartością oraz sterowanie } \\
\text { determinantami wartości }\end{array}$ \\
\hline Stweart G.B. & $1991 \mathrm{r}$. & Koncepcja EVA i MVA - mierniki wartości kreowanej \\
\hline Kaplan R.S., Norton D.P. & $1992 \mathrm{r}$. & $\begin{array}{l}\text { Koncepcja strategicznej karty wyników (Balanced } \\
\text { Scorecard - BSC) }\end{array}$ \\
\hline Edvinsson L., Malone M.S. & $1997 \mathrm{r}$. & $\begin{array}{l}\text { Koncepcja kapitału intelektualnego jako głównego } \\
\text { źródła wartości przedsiębiorstw, metody pomiaru } \\
\text { kapitału intelektualnego }\end{array}$ \\
\hline
\end{tabular}

Źródło: Szablewski A., 2008 r., Op. cit., s. 24.

Koncepcja VBM powstała w wyniku ewolucji metod i technik zarządzania strategicznego, począwszy od pełnej orientacji na produktach, poprzez kluczowe kompetencje, przewagi konkurencyjne, podejście zasobowe, skończywszy na strategiach rynku kapitałowego oraz kapitalizmu menadżerskiego i właścicielskiego. To właśnie inwestorzy działający na rynku kapitałowym są w koncepcji VBM nadrzędnymi podmiotami kontrolującymi skutki realizacji strategii produktowo-rynkowej przedsiębiorstwa oraz oceniającymi efektywność wykorzystania zasobów będących w posiadaniu jednostki ${ }^{23}$. W koncepcji tej silnie akcentowane jest znaczenie metod badania wpływu strategicznych wyników efektywności ekonomicznej przedsiębiorstwa na kształtowanie się popytu na jego akcje czy też udziały ${ }^{24}$. Pomiar dokonań jest niezwykle ważnym elementem VBM, ale stanowi on jedynie instrument zarządzania i narzędzie kształtowania wyników $^{25}$ - nie zaś wartość i ideę samą w sobie ${ }^{26}$. VBM jest ogniwem łączącym strategię działania $\mathrm{z}$ wynikami finansowymi, a jej skuteczność wymaga zgodności między podstawowymi procesami występującymi w przedsiębiorstwie, tj.: planowanie strategiczne, budżetowanie, sprawozdawczość finansowa, wynagrodzenie motywacyjne. Filozofia VBM jest uniwersalna na poziomie każdego przedsiębiorstwa, przy czym uwzględniając zmienność parametrów w czasie - jest stale kształtowana także w obrębie pojedynczego przedsiębiorstwa ${ }^{27}$.

Implementacja VBM jest niezwykle istotna dla skutecznej realizacji strategii wzrostu i rozwoju przedsiębiorstwa, ponieważ koncentruje się na metodyce zarządzania kluczowymi czynnikami, nośnikami, dźwigniami czy też siłami napędowymi wartości. Jak zauważają Copeland, Koller i Murrin², bardzo ważną częścią zarządzania przez wartość jest dogłębne poznanie i zrozumienie determinant wpływających na wartość

23 P. Szczepankowski: Determinanty wartości rynkowej spółek kapitałowych wczesnej fazy rozwoju, Wydawnictwo Vizja Press\&IT, Warszawa, 2013, s. 24.

24 J. Jeżak: Zarządzanie przedsiębiorstwem zorientowane na wzrost wartości dla jego właścicieli, Przegląd Organizacji, nr 5, 2001, s. 19-24.

25 A. Cwynar, P. Dżurak: Systemy VBM i zysk ekonomiczny. Projektowanie, wdrażanie, stosowanie, Poltext, Warszawa, 2010, s. 252.

26 L. Kamhi: Making Value-based Management a Way of Life, [w:] Arnold G., Davies M., Value-based Management: Context and Application, John Wiley and Sons, Baffins Lane, 2000, s. 197.

27 W. Pluta: Zarządzanie wartością w małych i średnich przedsiębiorstwach, Polskie Wydawnictwo Ekonomiczne, Warszawa, 2009, s. 38.

28 T. Copeland, T. Koller, J. Murrin: Wycena: mierzenie i kształtowanie wartości firmy, WIG-Press, Warszawa, 1997, s. 96. 
jednostek gospodarczych. Przeprowadzone przez Bughina i Copelanda ${ }^{29}$ badania na 2,7 tys. przedsiębiorstw pozwalają na jednoznacznie stwierdzenie, iż koncepcja oparta na zarządzaniu przez wartość dla właścicieli sprzyjała wzrostowi wydajności, poprawie efektywności oraz uwolnieniu niewykorzystanych zasobów. Oprócz niezwykle cennej perspektywy długofalowego, zrównoważonego rozwoju, stwierdzono ponadto, że koncepcja ta analizowana na poziomie ogólnokrajowym sprzyja zwiększeniu zatrudnienia dzięki uwolnieniu dochodu netto do gospodarki z wytworzonej wartości. W rezultacie zdiagnozowano również, że przedsiębiorstwa opierające swoje funkcjonowanie na dobrze dopasowanej do ich specyfiki koncepcji VBM uzyskują wyższy dochód na cele konsumpcyjne, poprawiają możliwości oraz perspektywy rozwojowe firmy i wytwarzają znacznie wyższą wartość dla właścicieli niż jednostki niezorientowane na zwiększanie wartości. Niestety koncepcja VBM nie jest pozbawiona wad. Poważnym problemem jest brak norm etycznych co z kolei może powodować pojawianie się nierzetelnych danych dotyczących rzeczywistej sytuacji finansowej przedsiębiorstwa. Przykładem może być chociażby Enron, Wolrd.com, czy Parmalat i Aholda $^{30}$. Poważnym problemem staje się luka między wartością fundamentalną przedsiębiorstw i ich bieżącą wartością rynkową, a w związku z tym dyskusyjna wydaje się być kwestia efektywności informacyjnej rynków kapitałowych. Może ona wynikać z odmiennych preferencji poszczególnych inwestorów, działan spekulacyjnych, niepełnej informacji czy asymetrii informacji.

\section{Rola interesariuszy i społecznej odpowiedzialność biznesu w ,nowej koncepcji" funkcjonowania przedsiębiorstwa}

Nowa filozofia prowadzenia biznesu powoduje, że pojawiają się poglądy wskazujące na konieczność maksymalizowania korzyści dla szerszego grona interesariuszy. Ich przejawem jest toczony $\mathrm{w}$ nauce finansów spór ${ }^{31}$ dotyczący konieczności realizacji przez przedsiębiorstwa koncepcji shareholder value (zarządzanie wartością dla akcjonariuszy, udziałowców - właścicieli) versus stakeholder value

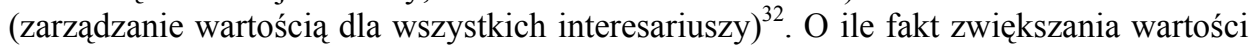
przedsiębiorstwa stanowi $\mathrm{w}$ literaturze przedmiotu condicio sine qua non, o tyle dyskusyjne jest przeznaczenie i podział tejże wartości ${ }^{33}$. W polemice tej wskazuje się często na powszechny kryzys zaufania i brak jakichkolwiek postaw etycznych prowadzących bezpośrednio do kryzysu całej cywilizacji industrialnej ${ }^{34}$. Według Penca $^{35}$, społeczna odpowiedzialność przedsiębiorstw jest przejawem wskazującym na potrzebę traktowania społeczeństwa jako integralnej części przedsiębiorstwa i wobec

29 J. Bughin, T. E. Copeland: Op. cit., 1997, s. 157-167.

30 J. E. Stiglitz: The Roaring Nineties. A New History of the World's Most Prosperous, PWN, Warszawa, 2006, s. 218-236.

31 L. Pawłowicz: Struktura rynku kapitałowego i akcjonariatu a zarządzanie wartością spółki, [w:] Zarządzanie wartością przedsiębiorstwa a struktura akcjonariatu, [red.] Pawłowicz L., CeDeWu, Warszawa, 2001, s. 13.

32 Y. Allaire, M. E. Firsirotu: Myślenie strategiczne, PWN, Warszawa, 2001, s. 28.

33 O. Harari: You're Not in Business to Make a Profit, Management Review, V. 81, No. 7, 1992, s. 53-58.

34 A. Toffler: Zmiana władzy. Wiedza, bogactwo i przemoc progu XXI stulecia, Zysk i S-ka, Poznań, 2003, s. 191-222.

35 J. Penc: Zarządzanie w warunkach globalizacji, Difin, Warszawa, 2003, s. 89. 
tego konieczności tworzenia pozytywnego wizerunku w tymże gronie odbiorców również, a może przede wszystkim, poprzez zachowanie wysokich standardów etycznych. Przedsiębiorstwo nie powinno zatem generować kosztów społecznych przerzucanych na konsumentów. Społeczna odpowiedzialność przedsiębiorstw wynika z siły społeczeństwa, co sprawia, iż firmy powinny funkcjonować jako dwukierunkowy, jawny system otwarty na sygnały $\mathrm{z}$ jego strony $^{36}$. Podejście określane jako „przedsiębiorstwo osób zainteresowanych” wskazuje na konieczność równoważnego godzenia interesów zróżnicowanych grup interesariuszy przez zarząd przedsiębiorstwa ${ }^{37}$. Postulat ten sugeruje traktowanie przedsiębiorstwa jako bytu społecznego a nie tylko czysto ekonomicznego. Podejście to akcentowane jest szczególnie silnie przez badaczy negujących neoliberalizm ${ }^{38}$. Zdaniem Szymańskiego, u podstaw koncepcji stakeholder value, co było szczególnie widoczne w czasie minionego kryzysu finansowego, leży postawa współczesnych państw wykazujących coraz mniejsze zainteresowanie i możliwości oddziaływania na sferę społeczną ${ }^{39}$. Powszechnie wskazuje się, że przedsiębiorstwo, jako podmiot stricte ekonomiczny, winno generować wartość dla dawców kapitału, właścicieli, natomiast to właśnie państwo zobligowane jest zagwarantować określone ramy działalności (instytucje) zapewniające respektowanie interesów różnych grup ${ }^{40}$. W podejściu do roli przedsiębiorstwa oraz znaczenia zarządzania przez wartość dla właścicieli, bądź też dla szerszego grona interesariuszy, widoczne są wyraźne różnice między poszczególnymi państwami, w szczególności między Stanami Zjednoczonymi i Wielką Brytanią a wieloma krajami europejskimi a także azjatyckimi. Różnice te wynikają z odmiennej struktury własnościowej, znaczenia oraz rozwoju rynków kapitałowych i w konsekwencji z powszechnych oczekiwań w stosunku do przedsiębiorstw a także państwa. O ile w Stanach Zjednoczonych cel działania przedsiębiorstw, będący określony przez prawo, wskazuje na konieczność dbania o interesy właścicieli (akcjonariuszy), o tyle w modelu europejskim częściej wskazuje się na potrzebę uwzględnienia interesów pozostałych grup. Model azjatycki, a w szczególności japoński, jest natomiast skrajną odmianą w którym dominującą grupą interesariuszy są pracownicy ${ }^{41}$.

Jak zauważa Davis, kierownictwo jednostki gospodarczej powinno podejmować decyzje w taki sposób, aby nie dążyć bezpośrednio do maksymalizacji zysku ani zwiększania wartości dla właścicieli, a zwiększać dobrobyt społeczny ${ }^{42}$. W praktyce jednak koncepcja ta, ze względu na szeroki krąg interesariuszy, jest niemożliwa do

36 A. Szablewski: Op. cit., 2004, s. 37.

A. Black, P. Wright, J. E. Bachman: W poszukiwaniu wartości dla akcjonariuszy. Kształtowanie wyników działalności spółek, Dom Wydawniczy ABC, Warszawa, 2000, s. 24.

38 M. Bojańczyk: Wycena i zarządzanie wartością przedsiębiorstwa w warunkach niestabilności rynku kapitałowego, Oficyna Wydawnicza Szkoła Główna Handlowa w Warszawie, Warszawa, 2011, s. 105.

39 W. Szymański: Kwestia społecznej odpowiedzialności przedsiębiorstw, [w:] Nauka o przedsiębiorstwie, [red.] Lichniak I., Oficyna Wydawnicza SGH, Warszawa, 2009, s. 163.

J. Żyżyński: Państwo minimalne czy państwo racjonalne, [w:] Gospodarka Polski 1990-2011. Transformacja. Modernizacja. Droga do spójności społeczno-ekonomicznej, [red.] Woźniak M. G., t. 3, Wydawnictwo Naukowe PWN, Warszawa, 2013, s. 275-308.

40 M. Bojańczyk: Op. cit., 2011, s. 107.

41 J. Bakan: Korporacja - patologiczna pogoń za zyskiem i władzą, Lepszy Świat, Warszawa, 2006, s. 48.

42 K. Davis, R. Blomstrom: Business and Society: Ethics and Stakeholder Management, McGraw-Hill, New York, 1975, s. 39. 
zrealizowania. Zdaniem Mathura i Kenyona ${ }^{43}$, koncepcja stakeholders wypacza zasadniczy charakter przedsiębiorstwa, które winno być pojmowane jako projekt inwestycyjny, w który zainwestowano środki po to, aby otrzymać więcej niż wartość wkładu. Brak jest w tym ujęciu jakichkolwiek moralnych obowiązków ciążących nad przedsiębiorstwem. Jak zauważają Brigham, Ehrhardt, Gessaroli i Nason ${ }^{44}$, w typowej, prawidłowej sytuacji koncepcja oparta na zarządzaniu przez wartość dla właścicieli prowadzi również do zwiększania wartości dla pozostałych grup interesów. Jak podkreśla Szczepankowski ${ }^{45}$, koncepcja oparta o zarządzanie wartością na rzecz wszystkich interesariuszy jest współcześnie przedmiotem powszechnej krytyki zarówno w rozważaniach teoretycznych, jak i w realnym biznesie. Zdaniem Ansoffa ${ }^{46}$, realizacja postulatów społecznej sprawiedliwości w obszarze tworzenia wartości może prowadzić do odmiennych od oczekiwanych skutków. Strategia przedsiębiorstwa jest wypadkową zdefiniowanych celów, odpowiedzialności oraz ograniczeń. Jej finalny kształt jest wynikiem kompromisu między różnymi interesariuszami. W zakresie rozważań etycznych pojawia się natomiast wątpliwość, czy osiagnięty konsensus jest w rzeczywistości wynikiem dążeń przedsiębiorstwa do poprawy dobrobytu społecznego, czy też odwoływanie się przez jednostki gospodarcze do społecznej odpowiedzialności jest jedynie zabiegiem marketingowym poprawiającym wizerunek firmy będący we współczesnych realiach koniecznym, przykrym obowiązkiem ${ }^{47}$.

W ujęciu teorii gier zauważyć należy, że relacje między właścicielami przedsiębiorstwa i pozostałymi interesariuszami nie mogą być traktowane jako gra $o$ sumie zerowej, gdzie wygrana właścicieli oznacza przegraną pozostałych grup interesu $^{48}$. W efekcie koncepcja oparta na kreowaniu wartości przedsiębiorstwa na rzecz właścicieli oznacza, konieczność wypracowania kompromisu, a wszystkie zainteresowane podmioty mają szansę na „wygrana”, co potwierdzają przykłady ze „świata realnego biznesu” ${ }^{\text {,49 }}$. Jak zauważa Bojańczyk ${ }^{50}$, klient jest usatysfakcjonowany w momencie zakupu produktu wysokiej jakości po niskiej cenie. Dla przedsiębiorstwa wysoka jakość oznacza zazwyczaj wysokie koszty, a niska cena - ograniczone przychody. Występuje rozbieżność interesów, ale właśnie poszukiwanie kompromisu pomiędzy interesariuszami wydaje się być kluczowym wyzwaniem we współczesnym rozumieniu zarządzania przez wartość. Posługiwanie się stwierdzeniem „maksymalizacja” względem którejkolwiek grupy interesariuszy może prowadzić do deprecjacji wartości przedsiębiorstwa, co przedstawiono na rysunku 1.

43 S. Mathur, A. Kenyon: Creating Value, Butterworth-Heinemann, Oxford, 1997, s. 335-337.

44 E. F. Brigham, M. C. Ehrhardt, J. Gessaroli, R. R. Nason: Financial Management, Theory and Practice, Elson Education, First Canadian Edition, 2011, s. 108.

45 P. Szczepankowski: Op. cit., 2013, s. 29.

46 H. I. Ansoff: Corporate Strategy, McGraw-Hill, New York, 1965, s. 5-6.

47 E. Luttwak: Turbokapitalizm, Wyd. Dolnośląskie, Wrocław, 2000, s. 27.

48 A. C. Shapiro, S. D. Balbirer: Op. cit., 2000, s. 8.

49 A. J. Slywotzky, D. J. Morrison, B. Andelman: Strefa zysku, PWE, Warszawa, 2000, s. 176. E. Królik, H. Wojciechowski: Tajemnice sukcesu Coca-Coli, [w:] Strategie wzrostu wartości firmy, [red.] Szablewski A., Poltext, Warszawa, 2000, s. 148.

50 M. Bojańczyk: Op. cit., 2011, s. 91-92. 


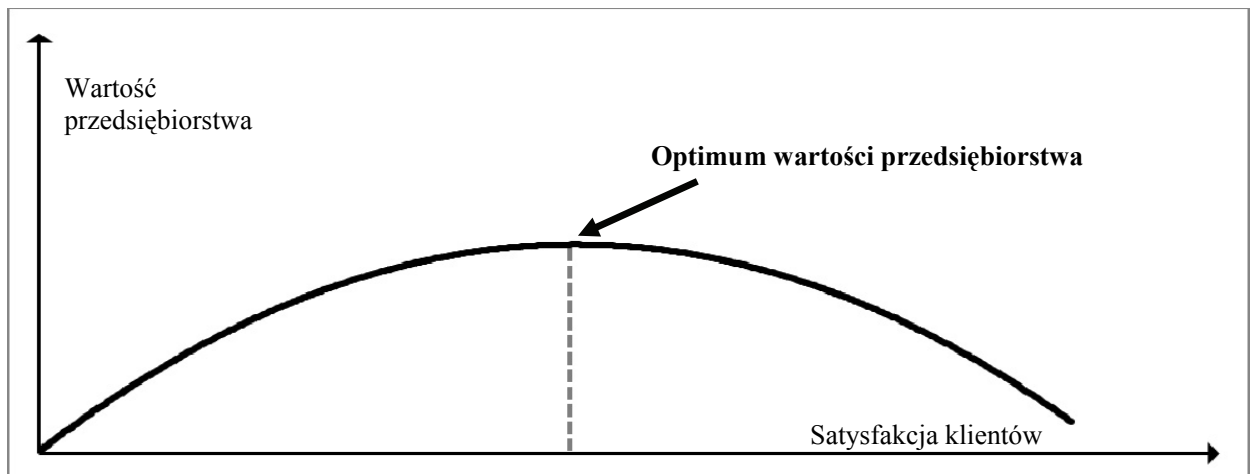

Rysunek 1. Satysfakcja klientów a wartość przedsiębiorstwa

Źródło: McTaggart J. M., Kontes P. W., Mankins M. C., 1994 r., The Value Imperative. Managing Superior Shareholder Returns, The Free Press, New York, s. 14.

Menadżerowie w ramach procesów decyzyjnych nie mają możliwości ignorowania zróżnicowanych grup interesów, ponieważ, jak zauważa Sunder ${ }^{51}$, przedsiębiorstwo jako organizm gospodarczy jest siecią kontraktów o charakterze formalnym i nieformalnym, a interesariusze sa jedną ze stron tej umowy. Zadowoleni interesariusze - głównie klienci - przyczynić się mogą do osiagniecia wyższej sprzedaży w przyszłości, co z kolei prowadzi do wzrostu wartości przedsiębiorstwa. W rezultacie usatysfakcjonowani są również właściciele, nastawieni na pomnażanie bogactwa reinwestują środki w przedsiębiorstwo, w tym również w personel. Usatysfakcjonowany i lojalny personel jest w stanie wytwarzać produkty lepszej jakości, które mogą przyczynić się do wzrostu zadowolenia ze strony klientów. Odstępstwo, na którymkolwiek etapie, od zasady dążności do zwiększania satysfakcji poszczególnych ogniw wspomnianego cyklu skutkować może deprecjacją wartości przedsiębiorstwa. Jak wskazują badania Younga i $\mathrm{O}^{\prime} B y r n e^{52}$, jedynie jednostki z dobrą reputacją w obszarze jakości, odpowiedzialności społecznej i środowiskowej oraz dbające o swój personel są w stanie uzyskać ponadstandardową cenę akcji na giełdzie. Jak zauważa Doyle ${ }^{53}$, w realiach ery informacyjnej to zarządzanie relacjami z klientami (CRM) stanowi główny element wytarzania aktywów marketingowych, tj. znajomość i świadomość marki, wizerunek firmy, relacje z klientami oraz partnerami handlowymi, budowanie długofalowych, trwałych i lojalnych relacji biznesowych. Aktywa marketingowe, zdaniem Doyle, stały się katalizatorem wartości przedsiębiorstw i wpisują się one w koncepcję zwiększania wartości dla interesariuszy, która pozostaje w zgodzie ze zwiększaniem wartości dla właścicieli ${ }^{54}$. Oczywiste jest zatem stwierdzenie, że budowanie wartości dla właścicieli nie jest możliwe bez dostatecznego uwzględnienia interesów innych zainteresowanych podmiotów.

51 S. Sunder: Theory of Accounting and Control, South-Western College Publishing, Cincinnati, Ohio, 1997, s. $14-20$.

52 S. D. Young, S. F. O'Byrne: EVA and Value-Based Management. A Practical Guide to Implementation, McGraw-Hill, New York, 2001, s. 13.

53 P. Doyle: Marketing wartości, Felberg SJA, Warszawa, 2003, s. 23.

54 G. Golik-Górecka: Wartość przedsiębiorstwa zdeterminowana relacjami z klientem. Zeszyty Naukowe Uniwersytetu Szczecińskiego. Finanse. Rynki finansowe. Ubezpieczenia, nr 55, 2012, s. 569-584. 


\section{Podsumowanie}

Dynamicznie zmieniający się świat biznesu wywołuje konieczność zdefiniowania na nowo istoty funkcjonowania przedsiębiorstwa. Wynik finansowy ustalony księgowo przestał być głównym celem istnienia jednostki gospodarczej, nie pełni także roli narzędzia służącego ocenie osiagganych rezultatów. Dlatego też pojawiła się koncepcja wartości przedsiębiorstwa jako nowego paradygmatu celu przedsiębiorstw. W tym kontekście pojawia się propozycja zarządzania wartością przedsiębiorstwa. Niestety powoduje ona także powstanie szeregu różnych dylematów. Jednym $\mathrm{z}$ nich jest pogodzenie oczekiwań ze strony szerokiego grona interesariuszy. Ma to szczególne znaczenie w dobie dyskusji dotyczącej społecznej odpowiedzialności biznesu i pogodzenia sprzecznych interesów przedsiębiorstwa i jego otoczenia społecznego. Jest to dylemat wymagający przeformułowania istoty biznesu. $\mathrm{W}$ odpowiedzi na potrzeby pogodzenia różnych grup interesów powstała koncepcja Value Based Management. Niestety, filozofia VBM nie wypracowała jednolitych standardów w zakresie proceduralnym, co sprawia, że brak jest możliwości przedstawienia uniwersalnego i transparentnego dla wszystkich przedsiębiorstw schematu implementacji i realizacji tej strategii. Prawdopodobna przyczyna słabości tej koncepcji jest wynikiem odmiennych preferencji poszczególnych inwestorów, działań spekulacyjnych, niepełnej informacji i asymetrii informacji. To jednak nie powinno zdecydować o zaniechaniu prac nad doskonaleniem tej koncepcji szczególnie $\mathrm{w}$ duchu zrównoważenia priorytetów właścicieli, społeczeństwa i gospodarki

\section{Bibligrafia}

Allaire Y., Firsirotu M. E.: Myślenie strategiczne, PWN, Warszawa, 2001

Ansoff H. I.: Corporate Strategy, McGraw-Hill, New York, 1965

Augier M., Feigenbaum E.: Herbert Simon - Biographical Memoirs, Proceedings of the American Philosophical Society, Vol. 147, No. 2, 2003

Bakan J.: Korporacja - patologiczna pogoń za zyskiem i władzą, Lepszy Świat, Warszawa, 2006

Black A., Wright P., Bachman J. E.: W poszukiwaniu wartości dla akcjonariuszy. Kształtowanie wyników działalności spółek, Dom Wydawniczy ABC, Warszawa, 2000

Bojańczyk M.: Wycena i zarządzanie wartością przedsiębiorstwa w warunkach niestabilności rynku kapitałowego, Oficyna Wydawnicza Szkoła Główna Handlowa w Warszawie, Warszawa, 2011

Brigham E. F., Ehrhardt M. C., Gessaroli J., Nason R. R.: Financial Management, Theory and Practice, Elson Education, First Canadian Edition, 2011

Bughin J., Copeland T. E.: The virtuous cycle of shareholder value creation, The McKinsey Quarterly, nr 2/1997, New York, 1997

Condor J., Goldstein J.: Value Based Management - The Only Way to Manage for Value, Accountancy Ireland, Vol. 30, I. 5, 1998

Copeland T., Koller T., Murrin J.: Wycena: mierzenie i kształtowanie wartości firmy, WIG-Press, Warszawa, 1997

Cwynar A.: Analiza porównawcza wybranych mierników zysku rezydualnego, Konsorcjum Akademickie, Kraków - Rzeszów - Zamość, 2000

Cwynar A., Dżurak P.: Systemy VBM i zysk ekonomiczny. Projektowanie, wdrażanie, stosowanie, Poltext, Warszawa, 2010

Damodaran A.: Finanse korporacyjne. Teoria i praktyka, wyd. 2, Onepress, Gliwice, 2007 
Davis K., Blomstrom R.: Business and Society: Ethics and Stakeholder Management, McGrawHill, New York, 1975

Doyle P.: Marketing wartości, Felberg SJA, Warszawa, 2003

Fera N.: Using Shareholder Value to Evaluate Strategic Choices, Management Accounting, November, 1997

Franc-Dąbrowska J., Kobus P.: Koszt kapitału własnego - dylematy wyceny, Zagadnienia Ekonomiki Rolnej 1 (330), 2012

Golik-Górecka G.: Wartość przedsiębiorstwa zdeterminowana relacjami z klientem. Zeszyty Naukowe Uniwersytetu Szczecińskiego. Finanse. Rynki finansowe. Ubezpieczenia, nr 55, 2012

Harari O.: You're Not in Business to Make a Profit, Management Review, V. 81, No. 7, 1992

Haspeslagh P., Nodo T., Boulos F.: Zarządzanie wartości firmy to nie tylko sprawa liczb, Harvard Business Review Polska, nr 7/2003

Jensen M. C.: Value Maximization. Stakeholder Theory and the Corporate Objective Function, Journal of Applied Corporate Finance, Vol. 14, No. 3, 2001

Jeżak J.: Zarządzanie przedsiębiorstwem zorientowane na wzrost wartości dla jego właścicieli, Przegląd Organizacji, nr 5, 2001

Kamhi L.: Making Value-based Management a Way of Life, [w:] Arnold G., Davies M., Valuebased Management: Context and Application, John Wiley and Sons, Baffins Lane, 2000

Koller T., Goedhart M., Wessels D.: Valuation. Measuring and Managing the Value of Companies, $4^{\text {th }}$ Editon, John Wiley and Sons, New York, 2005

Królik E., Wojciechowski H.: Tajemnice sukcesu Coca-Coli, [w:] Strategie wzrostu wartości firmy, [red.] Szablewski A., Poltext, Warszawa, 2000

Leibenstein H.: Poza schematem "homo oeconomicus", PWN, Warszawa, 1988

Luttwak E.: Turbokapitalizm, Wyd. Dolnośląskie, Wrocław, 2000

Maćkowiak E.: Ekonomiczna wartość dodana. Mierniki oceny kondycji finansowej i wartości przedsiębiorstwa, PWE, Warszawa, 2009

Majewski T.: Audyt wartości przedsiębiorstwa, Magazyn CEO, listopad, dostęp: www.ceo.cxo.pl, 2006

March J. G., Simon H. A.: Teoria organizacji, PWN, Warszawa, 1964

Mathur S., Kenyon A.: Creating Value, Butterworth-Heinemann, Oxford, 1997

McTaggart J. M., Kontes P. W., Mankins M. C.: The Value Imperative. Managing Superior Shareholder Returns, The Free Press, New York, 1994

Moszkowicz M.: Strategia przedsiębiorstwa okresu przemian, PWE, Warszawa, 2000

Nowicki J.: Zwiększanie wartości dla właścicieli a cel działania przedsiębiorstwa w teorii firmy, Zeszyty Naukowe Uniwersytetu Szczecińskiego, nr 737, Finanse, rynki finansowe, ubezpieczenia, nr 56, Szczecin, 2012

Pawlonka T. A.: Pomiar kosztu kapitału na przykładzie przedsiębiorstw branży mięsnej w Polsce: metodyczne studium przypadku, Wydawnictwo SGGW, Warszawa, 2016

Pawłowicz L.: Struktura rynku kapitałowego i akcjonariatu a zarządzanie wartością spółki, [w:] Zarządzanie wartością przedsiębiorstwa a struktura akcjonariatu, [red.] Pawłowicz L., CeDeWu, Warszawa, 2001

Penc J.: Zarządzanie w warunkach globalizacji, Difin, Warszawa, 2003

Pluta W.: Zarządzanie wartością w małych i średnich przedsiębiorstwach, Polskie Wydawnictwo Ekonomiczne, Warszawa, 2009

Rappaport A.: Creating Shareholder Value. The New Standard for Business Performance, The Free Press, A Division of Macmillan, New York, 1986

Shapiro A. C., Balbirer S. D.: Modern Corporate Finance. A Multidisciplinary Approach to Value Creation, Prentice-Hall, Upper Saddle River, New Jersey, 2000

Simon H. A.: Działanie administracji. Proces podejmowania decyzji w organizacjach administracyjnych, PWN, Warszawa, 1976

Slywotzky A. J., Morrison D. J., Andelman B.: Strefa zysku, PWE, Warszawa, 2000 
Stiglitz J. E.: The Roaring Nineties. A New History of the World's Most Prosperous, PWN, Warszawa, 2006

Sunder S.: Theory of Accounting and Control, South-Western College Publishing, Cincinnati, Ohio, 1997

Szablewski A.: Źródła i pomiar wartości firmy, [w:] Wycena i zarządzanie wartością firmy, [red.] Szablewski A., Tuzimek R, Poltext, Warszawa, 2004

Szablewski A.: Budowanie wartości i społecznej odpowiedzialności przedsiębiorstwa, [w:] Value Based Management - koncepcja, narzędzia, przykłady, [red.] Szablewski A., Pniewski K., Bartoszewicz B., Poltext, Warszawa, 2008

Szczepankowski P.: Determinanty wartości rynkowej spółek kapitałowych wczesnej fazy rozwoju, Wydawnictwo Vizja Press\&IT, Warszawa, 2013

Szymański W.: Kwestia społecznej odpowiedzialności przedsiębiorstw, [w:] Nauka o przedsiębiorstwie, [red.] Lichniak I., Oficyna Wydawnicza SGH, Warszawa, 2009

Toffler A.: Zmiana władzy. Wiedza, bogactwo i przemoc progu XXI stulecia, Zysk i S-ka, Poznań, 2003

Unzeitig E., Köthner D.: Shareholder Value Analyse. Entscheidung zur unternehmerrischen Nachhaltigkeit, Schäffer-Poeschel Verlag, Stuttgart, 1995

Wallace J. S.: Value-Based Management and Shareholder Theory: Substitutes or Complements?, Working Paper, University of California, Irvine, 2002

Young S. D., O'Byrne S. F.: EVA and Value-Based Management. A Practical Guide to Implementation, McGraw-Hill, New York, 2001

Żyżyński J.: Państwo minimalne czy państwo racjonalne, [w:] Gospodarka Polski 1990-2011. Transformacja. Modernizacja. Droga do spójności społeczno-ekonomicznej, [red.] Woźniak M. G., t. 3, Wydawnictwo Naukowe PWN, Warszawa, 2013

\section{Summary}

Business activity requires the prior definition of the aim of the company and identify the measures to achieve this goal. The reflects of the philosophy of the company activities are mission and vision defined as the strategic aims and operational aims. The strategy is a kind of expression of accepted business concept and the specific ways in which the companies maintain favorable stability from their surroundings. The aim of the article is to present different concepts of value management in the context of treating them as the essence of the enterprise being. This scientific article is a review.

Key words: Value of enterprise, value based management, profit

Informacja o autorach:

Dr Tomasz Pawlonka

e-mail: tomasz_pawlonka@sggw.pl

Adres: ul. Smagliczki 12/1, 05-500 Nowa Wola

Dr Joanna Bereżnicka

Katedra Finansów

Wydział Nauk Ekonomicznych, Szkoła Główna Gospodarstwa Wiejskiego w Warszawie

ul. Nowoursynowska 166

02-787 Warszawa

e-mail: joanna_bereznicka@sggw.pl 